\title{
HISTOPATHOLOGICAL OBSERVATION ON THE MORPHOLOGICAL ANOMALY \\ OF THE AREA OF SULCUS OLFACTORIUS \\ - COMMENT ON THE INFLAMMATION OF SULCUS OLFACTORIUS -
}

\author{
By \\ T. KITAJIMA M.D. \\ From the Department of Oto-Rhino-laryngology, Nippon Medical College \\ (Chief: Prof. T. Daito)
}

Sulcus olfactorius nasi has a great significance as osmatic locus, but great deal of its specific anatomy, structural state and also of morphological abnormalities remain still unknown.

From autopsied 47 cases, ranging from the new born to the age of 74 years old, the nasal septum, the upper and the middle meatus on both sides and the ethmoid together with the ethmoidal canopy and the lamina orbitalis were taken out as a whole entity, preserving the structural relation of each other; and the specimens of the 47 cases, that is, 94 materials for both sides ( 9 cases for $0 \sim 4$ years old, and 38 cases for over 17 years old) were prepared for continuous serial section of the frontal occiput for histopathological examination. The obtained result is as follows:

1) Morphology of sulcus olfactorius is very complicated, and there are some observed with stricture, closure and adhesion. The absolute number of adhesion is relatively of low rate.

2) When delicate differential diagnosis between the closure and the stricture is required, artifact in the process of preparation of the specimens should be taken into consideration.

3) Any findings transgoing from closure to adhesion are hardly found. In such area as sulcus olfactorius with narrow space and exposed to the chance of infection, the possibility of the closure proceding to the adhesion due to inflammatory change is recognized. In other words, both clinically and histologically inflammation of sulcus olfactorius is to be regarded to exist.

4) Among the specimens of the new born, the mucous membrances of the middle meatus and the nasal septum are sometimes observed to become adhesive and the sulcus closed. This is considered as congenital anomaly of sulcus formation.

5) Therefore, the adhesion of sulcus olfactorius among the adult cases are not always of inflamatory change, and it is now revealed that the etiology of the change exists in.

i. congenital malformation of sulcus olfactorius originated from the embryonic stage

ij. acquired morphological anomaly of sulcus olfactorius plus inflammation due to the overgrowth of ethmoidal cells.

It is, however, very difficult to presume its etiology from the finding of organizing adhesion.

6) Clinical significance of the abnormality whether it is of congenital malformation of acquired inflammation or acquired inflammatory adhesion of sulcus olfactorius is great and should not be neglected. 


\title{
嗅裂部形態異常に関する病理組織学的観察
}

\author{
一嗅裂炎飞対する私見一
}

\section{日本医科大学耳鼻咽喹科教室（主任：大滕般三教授）}

北崔嶋拨忘

I 緒 言

\|検索成 績

1. 検索資料及び梌索方法

2. 資料の年令的区分

3. 嗅裂部異常例について

i) 接着嘴着症例

ii）瘾着症例について

A）新生胃に認められた裙着様所見にっいて

B）成人群に和ける䇻着症例飞ついて

a) 瘾着側

b) 瘾着部位, 籁围

c) 滤着症例の病理組織学的所見

III 総括並びに考按

1. 咱裂部接着について

2. 新生児に認められた港着梯所見についての检討

3. 成人群に怙ける痖着症例についての検討

4. 接着之瘜着との関倸

5. 嗅裂部形態哄常の臨床的意義

N 結 論

\section{I 緒 言}

我々耳鼻咽唉科臨床に携る者にとつて，慢性副鼻腔炎 経手術患者において，猶乞の愁訴の軽減されない症例に 遭遇する事は稀でない。

その原因の一端として，副鼻腔と櫁接な関俰にある固 有鼻腔に対する適切な処置を欠いている点に気付く場合 がある. 即ち慢性副鼻腔炎に対する処置は, 副舅腔手術 のみをるつて能事足れりとする傾向のある事は否定でき ない臨床上の事実である。しかし作ら相即不離な因果関 保にある固有舅腔に対する適切な処置を加党る事の重要 性は，今更喋々する必要の無い事であるう，即ち固有鼻 腔湢睤腔への感染系路であると共に，分汹物排泄路で 古り，呼吸気流の大道でもある。斯く解剖学的に生理学 的に，病理学的比一連の機序を営えで存在するものであ

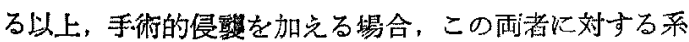
統たつた認識の下に，病態をより正常化せんとする努力
が必要なのである。

昭和 34 年 6 月, 日耳與関東地方会第 361 回例会, 及 び昭和 35 年 5 月, 日耳鲌第 61 回総会に打いて，高橋教 授は咱裂部異常状態汇注目され，臨床解剖学的に，病理 組織学的に尼体標本多数例検索の結果之，臨床的経験上 り「嗅裂炎」なる病態を提唱され，その臨床的意瑏を强 調された。

この研究は剖㷿屍体上り独得な方法で，顔面を損傷せ ずに鼻腔・副鼻腔を立体的関係を保たせ乍ら剔出し，大 標本として前頭断組職標本老作製観察したものであり，

夥しい努力と忍耐を必要とするものであつて，この剔出 法のみを採り上げても㓣目に価する業績である。しかも 前頭断組䢂標本によつて，奥中隔と鼻聜側壁をな小甲介 壁との関係を追究した事実は，彷来の晒頭蓋に括ける粘 膜欠除標本に抢沙る研究，あるいは鼻腔側面からの観察 とは異り綿密且精確を梂め，局所解剖学的に更に臨床的 に大なる意義がある，特に現在迄臨床的等䦥視されて いた嗅裂梁部に亘る異常状態を，鼻中隔之節骨蜂简との 立体的位置構造を保ち乍ら追究し得た点で敬意を衰する 次第である。

扨て私も同様な期点から嗅裂部の異常形態に着目，例 究観祭を行い，教授が発表される都度，自己梌窈成績に 基く結果を中心に見解を追加するいは筫問してきた。こ 入に私の研究成績を一括して述べるが，この分野の砳宽 発展に聊かなりとも貢献するところあらば幸である。

\section{II 検索成樍}

1. 梌索資粠及び梌索方法：

拙著「副鼻腔骨壁の 組織学的研究」(耳展, 第 2 巻補 册1 揭載）飞詳記せし故省略する。

2. 資档の年令的区分：

$$
\left\{\begin{array}{rrrr}
\text { 小思啡 } & 4 \text { 才以下 } & 9 \text { 例 } & 18 \text { 例 } \\
\text { 成人群 } & 17 \text { 才以上 } & 38 \text { 例 } & 76 \text { 侧 }
\end{array}\right.
$$

以上の如くに大別，更に务の年令的区分を示士上，第 1,2 表の如くである. 学童期の症例を欠いているのが残 念であるが，この年令筧は標本嵬收に際し最も得難いの 
第 1 表

\begin{tabular}{|c|c|}
\hline 年 令 & 症例数 \\
\hline 新 生 児 & 1 \\
\hline 15日 & 1 \\
\hline 2力月 & 2 \\
\hline 5 力月 & 2 \\
\hline 10力月 & 1 \\
\hline 1苏6力月 & 1 \\
\hline 47 & 1 \\
\hline 計 & 9 \\
\hline
\end{tabular}

第 2 表

\begin{tabular}{|c|c|}
\hline 年 令 & 症例数 \\
\hline $17 \sim 20 才$ & 4 \\
\hline $21 \sim 30 \gamma$ & 6 \\
\hline $31 \sim 40 x$ & 5 \\
\hline $41 \sim 50 \Varangle$ & 7 \\
\hline $51 \sim 60 才$ & 5 \\
\hline $61 \sim 70-\checkmark$ & 7 \\
\hline $71 \sim 80 才$ & 4 \\
\hline 計 & 38 \\
\hline
\end{tabular}

が現状である。

3. 嗅裂部異常例について：

i）接着癒着症例. 第 3 表の如くである.

\section{第 3 表}

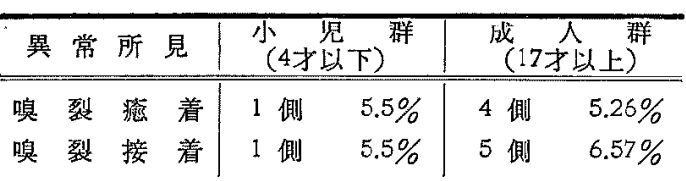

但し第 3 表に示される接着例は巨視的溦視的汇真正 と考克られるものであって，二次的人工的接着例は次の 如くである、

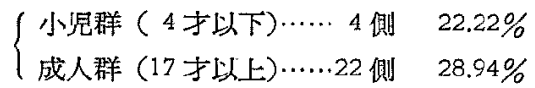

こフに私の言ら二次的接着とは，屋体より標本を取材 する際の外力により，あるい組織切片作製途上に括い て起つたと思われる人工的鼻中㢳・甲介賠の接着の事で ある・即ち斯かる際生じた

鼻中陽骨折，及び篩骨正中板・鼻中滆軟 骨接合部の転位

亶中瀜骨あるいは軟骨からの粘膜の剝離

上・中甲介骨梁骨折

上・中甲介骨宲からの粘膜の䟝離

籍骨蜂窝骨梁骨折

等によつて起つた，あるいはこれ等が関与したと考えら れる接着であつて，概れ微視的に精細に推察しなければ 解らないるのが多い，仮令接着局所に認めなくとも，周 因あるい猿隔の䉯処にこれ等が存在し，且古体的相互 関係から，それが接着の原因となつたと考えられるもの は総て含めた．従つてこの二次的接㵽群を真正接着群に 加えると，接腯例総数は

$$
\left\{\begin{array}{l}
\text { 小見群 ( } 4 \text { 才以下) ……5 側 } \quad 27.77 \% \\
\text { 成人群 (17 才以上) } \cdots \cdots .27 \text { 側 } \quad 35.52 \%
\end{array}\right.
$$

となる. 故に上記瘉着・接着例総てを含めた嗅裂部形態 異常忧

$$
\left\{\begin{array}{l}
\text { 小児群 ( } 4 \text { 才以下)……6側 } 33.33 \% \\
\text { 成人群 (17 才以上)……31 側 } 40.78 \%
\end{array}\right.
$$

の如き頻度を示す事になつた。

ii) 癒着症例について

A）新生胃に認められた瘉着様所見について 小它群に和いて唯\& 1 例 1 側の及㖵裂瘉着様所見を認 めたこの症例は右側喚裂㰅度開放状であるにる拘ら す，左側は概ね接着状を示し，特汇連続切片に和ける観 察によると，その中方中前部に和いて，嗔裂上部及び 下部の 2 ケ処限局性に中甲介粘膜と中隔粘膜が癒合する 所見を呈した。即ち嗅裂上部に和いては，異所的形成を 営んだと想像される新生骨（一部軟骨性化骨を営んでい る）が，學中隔粘膜固有層之中甲介粘膜固有層の間に存 在，発育を継続し，骨芽細胞の存在り認められる．周囲 の上皮層は摡枚則正しく新生骨上下部を团繞し，その 儘中瀜，甲介上皮倜へと移行している。この新生骨 の発生母地は左中甲介上皮下固有層であるらしく，前端 部は左中甲介鄙裂部粘膜上皮下に存し，後部では㭘む左 中甲介〜鼻中嵒粘膜に跨つた位置にあつて大きくなり， 更に後部では軟骨性化骨を営む部分となり，最後部で注 骨は認められず接着へと移行している。この新生骨を認

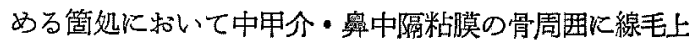
皮を認めす，規則正しく粘膜固有層が配列している所見 は，この骨片が館迄も異所的過剩增生を営んだ䧽生骨で あつて，標本取材時，あるいは作製経過に和引る迷入物 で無い事を証明している．恐らくこの新生骨は胎生期鼻 腔到與腔形成の際に原基があつたであろうと想像され る. 所見と乙ては中甲介あるいは上甲介骨梁の一部の過 剩增生と考えるのが妥当のよらである，従つて中甲介 鼻中隔粘膜は，この新生骨の存在する部分に扣いて互い に癒合移行している訳である。

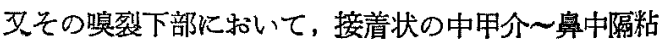
膜の一部が上皮膡を失い，癒着榜所見を呈している.切 片によつては2〜3の都生骨が，あるいは脂肪組織が両 粘膜瘉合部に存在している。特徴的であるのは左側篩骨 蜂简 (特に前部) の発育, 形成状熊が，右側に比して甚 だ夫熟且抑别的であり，とのため（眼窩紙様板が中甲介 骨梁に極めて接近し）部位によつては中甲令骨梁即眼䆟 紙様板と考えられるような所見を呈し; 眼䈑内脂肪組織 


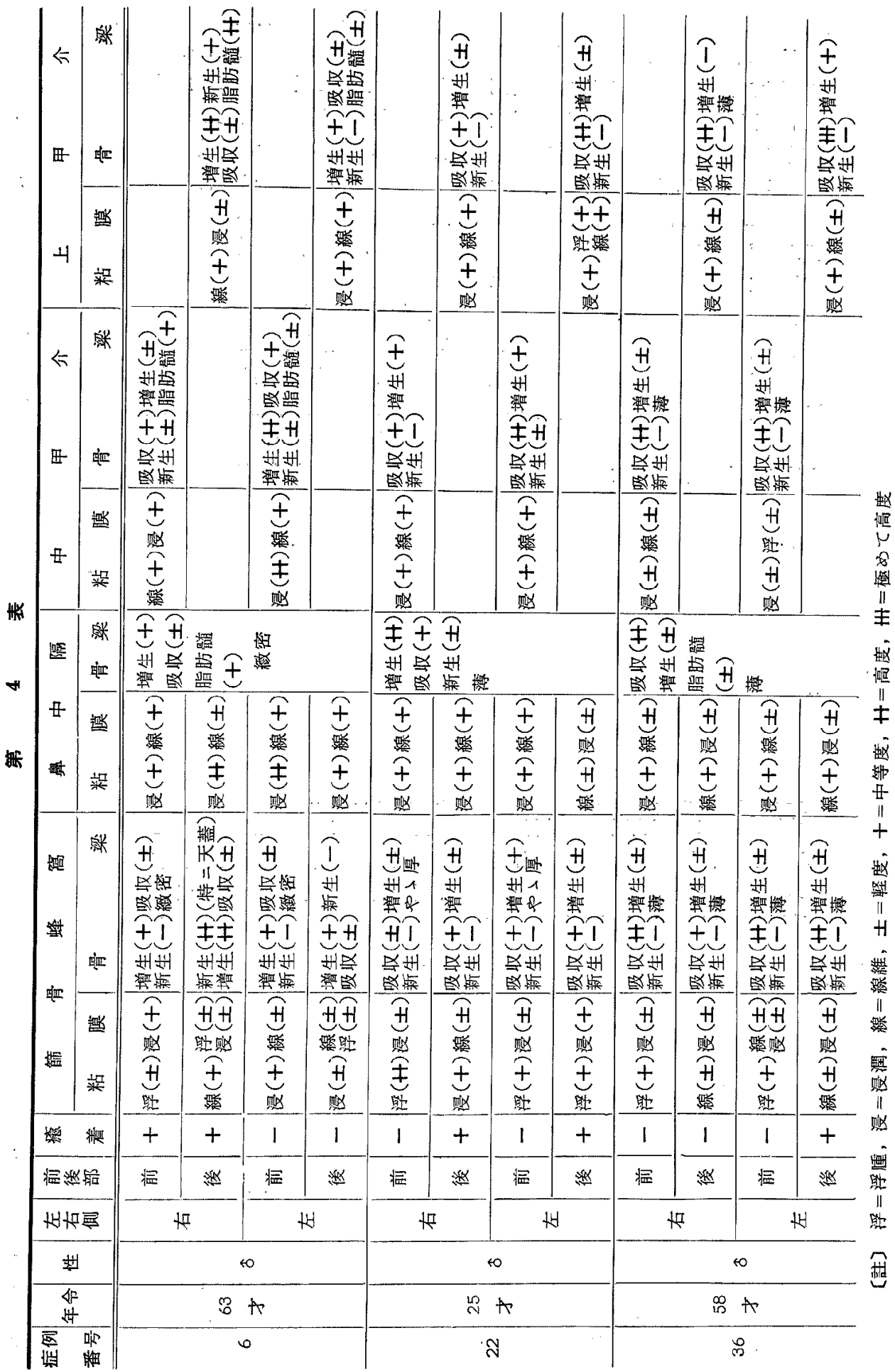


が本来ならば中甲介骨梁であるべき骨梁に接して存し， これが中甲介骨梁を越えて内側に発有する所見も認めら れる、極めて小なる屍体より顔面を損傷せずに且短時間 に取材しているため，小標本となり，鼻中隔下部迄追究 し得ないのが残念であるが，他の小照例においては斯か る猗型を呈するものは 1 例飞無く，概水咱裂部の広さは 適度のものが多からた：この真裂下部の所見も，当初は 眼简内側組織の迷入したものでは無かららかと慎重に検 討し，更に $2 \sim 3$ の専門家の意見を問うたが，皆一様に 「二次的迷入に非ず」との見解であつた。

即ちこの症例は罟裂上部及び下部の 2 ケ所において， 瘾磨様所見 (癒合) を呈している事が，周团との関保及 び局所の組織構成から理解されるのである（付図 No. 7, No. 8)

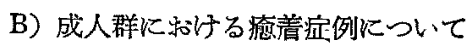

成人群に認められた瘉着例は，3 例 4 侧であつた（両 側瘉着例 1 例を含む).

a 癒着側 $\left\{\begin{array}{lll}\text { 右 } & \text { 側…… } & 2 \text { 側 } \\ \text { 左 } & \text { 側…… } & 2 \text { 側 }\end{array}\right.$

上記の如く，瘉着泟例数が少いためか，左右差は認めら れなかつた。

$\mathrm{b}$ 癒着部位, 範囲

症例 6 , 右側, 中甲介中前部（喚裂中上上部）に括い て限局性に小部分に始り, 上甲介の中後部迄䇗着. 上甲 介の上下径は殆んど全域に亘り広範囲に癒着.

症例 22 , 右側, 中甲介後部から上甲介移行部に 始り, 上甲介は殆えど後部迄広範囲性愈着. 左側, 中 甲介後部に执いてのみ限局性に癒着。

症例 36. 左側, 㗘烈上部に虬いて, 上甲介前部より後 部（殆んど最後部）迄癒着.

即ら部位及び範围を簡単に要約すれば

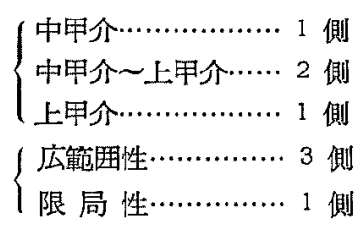

以上の如くなる。即ら中甲介後部より上甲介にかけての 啋裂疮着が多い，又連続切片に上る観察では，上下径の

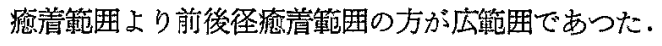

\section{c 疮着症例の病理組織学的所見}

第 4 表の如く，渝着側の舜中隔，上・中甲介，飭骨蜂 简粘膜及び骨梁に，特別目立つた高度の炎泟性変化は無 く、特に同一症例に叔ける疮着側と非瘉着側に知んど差

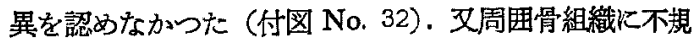
則且複雑な所見を認め得す，それらは概小静止状態であ り過去の発青経過に打いて, 粘膜の炎症性病変の甚しい 影響を蒙つたるのとは考えられない所見であつた，更に 言及すべきは，接着より瘉着へ移行せんとする Process を示す明瞭な所見は殆んど得られず，全例瘉着完了し機 質化したと考えられる Stationär のもの許りであつた 事である. 残念乍ら癒着症例少数のため, 非瘉着症例群 との比較を試みる事は不可能であつた。

又新生児例に打ける疮着様所見症例は，骨芽細胞を伴 いあるいは靯骨性化骨を営みつつ生々発育を続ける所見 で，甲介その他の粘膜る生理的範囲の細胞浸㵎潤呈す るのみであり，何等病的变化を示するのでは無く，この 表には含めなかつた。

\section{III総括並びに考揬}

1. 唤裂部接着について

多くの標本を観察して，かなりの頻度で喚裂部が狭小 状態を呈するるのつあるのは事実である．特に上甲介部 に和いては，その傾向大であつた：しかし乍ら接着をき たしているすのは比較的少い，一方巨視的には接着所見 を呈するが，微視的に精細に追究して二次的 (人工的) 接着と考えられたるのはかなりの\%に認められた（付园 No. 1 No. 4).

即ちこの標本を骨壁を中心とした大塊として屍体より 取材する際、相当な外力が専ら外側上り内側へ向って加 えられるのである．且完成された切片標本が如実に物語 る如く，笁骨蜂荅外側即ち紙様板下部及び症例によつて は中甲介下部に強い支柱が無く、この部は遊離状である 場合が多い，冬正中部の鼻中隔も下部は遊離状であり， 骨質の性状及び蜂简発育の状態によつては，両者は夫々 想像以上に可動状を呈する場合もある。従つて鼻腔外側 壁をなす中上甲介と鼻中隔とが，標本取材の際の外力， あるいは固定・脱灰々の他の操作過程に和いて，検索成 績の項で述べた如き現象により，二次的代接着状態を薏 起する可能性のある事が考文られる。句諭作裴せる切片 標本が与克る印象よりは，剔出せる大塊標本は安定した ものではあるが，实質性臓器で無く含気蜂简を内蔵し た部分であり，骨壁の厚さも種々であるが故に，斯かる 二次的人工的影響を無視する事はできないと考える.

又剔出大塊は骨・軟骨・粘膜から成り, 可能な限り薄 切せえがために脱灰液 (著者は Plank \& Rychlo の迅 速脱兏法によつた）に長時間浸漬した上で Celloidin 包 埋を行はなければならない，ために斯かる標本を作製す 
る場合，骨あるいは軟骨からその周囲組織たる粘膜が剝 離する事る，ある程度は止むを得ないようである。

故に狭小か接着かのデリケートな問題を追究する場 合，このような二次次的現象を決して等閑視する事はで きないのではなかららか．勿論それが巨視的に明膫なむ のは標本より除外したが，それでもかなりの\%に二次的 人工的接着例を認めた。

叉一方生体に秃いて喚裂の接着状を呈していたもの か゚，標本剔出時に離れ，より開放せられる場合る稀には あり得ると想像される。

Ash 及び Raum の「Atlas of Otolaryngic Pathology」揭載の，天蓋壁，鼻腟底及び笠骨洞を含む鼻腔後 部の頭蓋切片の標本写真には，「標本作製途上の骨折炕 伴う鼻中隔禁曲及び穊骨蜂䈑の变形」との附記があり， その他「人工的産物としての中隔軟骨よりの粘膜剝離」 々説明された顕溦鏡写真も示されている。即ち斯かる支 柱のある標本及び切片でも，人工的骨折のある場合もあ り，粘膜剝離む避け難いのであるから，下部に支柱を欠 く私の標本では，これ等の現象が不可抗力の場合もある 上うである.

従つて斯かる二次的と考党られる症例を除くと，真正 接着例は甚だ少数であつた。当然の事乍ら，骨折等を認

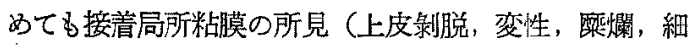
胞浸潤等) から真正接着と看做した症例もある。

2. 䉼生児に認められた癒着様所見についての検討

この症例の局所々見に関しては既に述べた。

双てこの症例は，小坚群中㩚か 1 例 1 側ではあるが， その意義は大である. 勿論小肾群症例少数で，その\%は 正鴻を得たものではない：しかし死因（隥落分婏死）及 び局所粘膜，骨所見から勘案して，一旦形成せられた嗅 裂が，後天的炎淀性变化による影響を受けて，二次的に 疻着したものでない事が明らかであり，この嗅裂部癒着 様所見は先天性嗅裂形成異常（あるい:嗅裂発育異常） によるものであると考觉られる，敛密な断定を下すに は, 当然胎生学的に鼻腔副鼻腔発育の経過, 及び嗅裂成 立の実態を把握する必要があり，この問題に関しては現 在鋭意研究続行中である。

こつで斯かる先天性臭裂形成異常例が生存し，発育成 長した場合を仮定想像してみよう，発生学的に䇫骨蜂 简・鼻中隔等の発育と共に，喚裂々のもの>間腔も㹡大 される傾向を有するのであるから，新生児期当初のこの 時期に嗅裂が瘉合閉塞していても，将来鼻中隔と甲介壁 とは次第に離れてゆく運命にあるのかも知れない。しか
し骨梁の存在による泌な,連絡, 並びに篩骨蜂營の内側へ の膨隆之言5，生後の鼻腔側壁発育成長の可能性を考克 れば，蜂简の原始時代とも言うべきこの時期の所見は， 寧るこの状態の儘で推移するか，あるい現在以上㳊軟 骨性化骨及び骨增生も著明となり，鼻中隔と甲介とは一 層広範囲且強固な㾤合を遂げると想像する方が妥当では なかららか。

又異常側が正常側に比して，篩骨蜂窝形成不良である

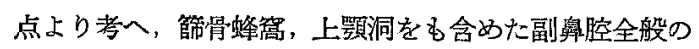
通気分泌排泄障碍の因となり, 蜂窝発育未完成の生後早 期に县副鼻腔炎を惹起する傾向があるのではなからう か. 勿論推論に過ぎないが, 斯かる解剖学的異常例が， 不可逆的な重症の新生児上顎洞炎あるいは節骨洞炎を㟟 起し，更に骨䯣炎を招き易い可能性を有寸るのではなか ろらかと想像する。

3. 成人群火おける疮着症例についての検討

疮着例の各部位に亘る粘膜, 骨所見の概観に関しては 既に一括して述べた，広範围な大標本を観察するのであ るから，一局所拘泥する事なく所見を整理する必要が ある.例は筑骨蜂窩粘膜所見の判定に際しても，手術時 剔出せる小片による従来の観察とは異り, 部位により特 徵を呈し, 同一篣骨蜂窩でも中鼻道附近, 天蓋壁部, 紙 椂板側上夫々異同を示高場合が多い，徒つて第 4 表はそ れらの所見を概括したものである。

文粘膜所見に関しては，この標本は専ら骨壁を主体と した大塊であるから，いか沉徽底した脱灰を行い，薄切 せんと心郝けても，その厚さには限界があり，一般の軟 部組織切片標本の数倍となる可能性が多い，従つて粘膜 組織の所見は誇張された状態で観察され易い，故に検者 自身の主観によりある程度の異同が生ずる事る避け得な いと思う．以上の事項を先ず念頭に置く必要がある。

既火述へた如く，同一症例に和ける癒着側と，非痹着 側の炎症性病変の所見は, 骨梁, 粘膜共に著明な差を認 めない上うである。即ち㾑着側の炎泟性所見が特に高度 である症例は存在しなからだ. 又標本取村時の肉腿的観 察に沶いても，3 例共に膿粘液貯溜，粘膜肥厚等は認め られず, 現在進行状熊の炎症性病変を呈するものとは考 点られなからた。

撚着局所の所見 :

症例 6. 連続切片で前部より後部へ観察してゆくと， 右側中甲介中前部の極く限局した小籍囲の部分に瘉着は 始つて皎り，次第に広範囲となり，切片面で閉塞された 形の上部嗅裂は，更に一々処㾑着を生じ，嗅裂最上部は 
喘視的に連続切片で遂次観察しなければ認められない程 狭且小となり，同時に上甲介内側面が全長に亘り，完全 に近い程中隔と瘉着し，殆儿ど咱裂は閉塞状である事が 解る. 更に後部に到ると漸く癒着終末点に達し, 上甲介 は独立し喚裂は開放されている、この間裂・上甲介・ 上番道・中甲年を含め, 右側節骨蜂简は実に複雑な形態 を示している。

この標本に蛞ける瘉着局所の粘膜所見は, 鼻中隔・甲 介共に上皮下組織は移行し合い，所々に上皮組織は残存 し，一蜂筬の如くInsel を形成している. 固有層はや 子線維性であるが，節骨䗋弪粘膜る線維性傾向多く 現 在炎症は軽度で癒着しつ」ある所見でない事を示してい

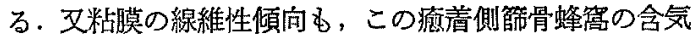
化状態不良（抑制）である事に起因していると考兄るの が妥当で西万弓（付図 No. 9 No. 22).

症例 22. この症例の喚裂部は，両側共数ケ処で癒着 し，上皮の一部が多数 Insel 様に残つている. 鼻中隔 と上・中甲介の上皮下組織は極めて自然に移行しあい， 焱症所見は概补中等度である. 乙かし上皮には变性像無 く，現在炎症时進行しているものとは認め難く，癒着し つ๖あ所見では無くStationär な所見と言えよう （付図 No. 23, No. 24).

症例 36. 左側上甲介と鼻中㢳に癒着を数ヶ処認め, 上皮が Insel 様使り，蜂筒形成像の如き所見である. 一般飞炎症性所見軽度で，線維性增生著明で無く，Stationär な所見であり，骨梁は韭薄であるが 複雑な変化 像惊さない（付図 No. 25〜No. 32)，

以上の如く3 例共に，現在焱症性変化楞しく癒着しっ つある所見では無く，既に完成され機質化した㴰着像許 りであり, Stationär なるの許りであつた。

これ等㾋着症例を，連続切片で前部より覞察してゅく

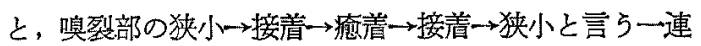
の関係は認好られるが，この所見が接着から現在瘉着へ 進行しつ১ある状態として，追究できたものは1例も存 在しなからた，癒着しているものは歴然たる瘉着であ り，接着所見は固定した接着であつて，同者の移行形は 見出し得なからた。

\section{嘴着例の蜂管発育所見:}

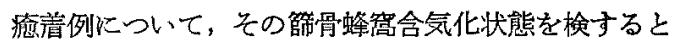

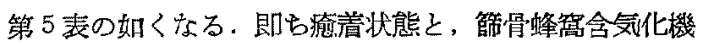
䩪との間に，特に関倸は認められないようである。この 問題に関しては次項において更に述べる。

4. 接着と㾑着との関保

\begin{tabular}{|c|c|c|c|c|c|c|}
\hline \multirow{2}{*}{$\begin{array}{l}\text { 症例 } \\
\text { 番号 }\end{array}$} & \multirow{2}{*}{ 側 } & \multirow{2}{*}{ 癌着 } & 篩 & 骨 & 蜂 & 簥 \\
\hline & & & 含気化状態 & 粘 & 膜 & 骨＼cjkstart梁 \\
\hline 6 & $\begin{array}{l}\text { 右 } \\
\text { 左 }\end{array}$ & $\begin{array}{l}+ \\
-\end{array}$ & $\begin{array}{c}\text { 不良(㧕制) } \\
\text { 中不良 }\end{array}$ & $\begin{array}{r}\text { 線 }(+) \\
\text { 線(士 }\end{array}$ & $\begin{array}{l}(+) \text { 浮 }( \pm) \\
( \pm)\end{array}$ & $\mid \begin{array}{c}\text { 厚, 緻密 } \\
\text { p」厚 }\end{array}$ \\
\hline 22 & $\begin{array}{l}\text { 右 } \\
\text { 左 }\end{array}$ & $\begin{array}{l}+ \\
+\end{array}$ & $\begin{array}{l}\text { 中不良 } \\
\text { 中不良 }\end{array}$ & 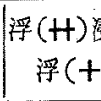 & $\begin{array}{l}(+) \text { 線(土) } \\
\text { 曼 }(+)\end{array}$ & $\begin{array}{l}\text { p小厚 } \\
\text { や小厚 }\end{array}$ \\
\hline 36 & $\begin{array}{l}\text { 右 } \\
\text { 左 }\end{array}$ & - & $\begin{array}{l}\text { 極めて良好 } \\
\text { 極めて良好 }\end{array}$ & 浮 $(t)$ & $\begin{array}{l} \pm) \text { 浸 (士) } \\
\pm) \text { 浸 }( \pm)\end{array}$ & $\begin{array}{l}\text { 菲 } \\
\text { 菲 }\end{array}$ \\
\hline
\end{tabular}

抑々㧝烈部粘膜は，固有鼻腔粘膜としては，他の部位 より炎症性所見は軽度である場合が多く，概社上気道粘

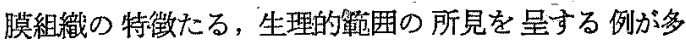
い. 組織学的には細胞浸潤, 浮揰等は比轒的軽度であ る.しかし乍ら空隍に余唒が無いため，節骨蜂窩炎，蝶 形骨洞炎等の二次的影響を受け易い部位である事は，局 所解剖学的飞も推論可能である.高橋教授は夙にこの点 に差目され，「嗅裂の狭小接着状態のものは，副鼻膑炎 を起し易く，その結果嗅裂部粘膜の㾍着をきたす」とさ れ、「検索例中高率に 見られる 嗅裂瘾着は, 炎症性の結 果であつて, 決して先天性のもので無い」と推論されて 括り,「瘉着は接着の病的状態であり」「狭小・接着部に 炎症が存すれば，その結果として癒着をもきたすと到る 段階が明膫観察し得られた」と述べている。

教授の主唱される如く，局所解剖学的に空鄚に余唒の 無い，且周囲が骨壁により固定された唤裂部粘膜が，炎

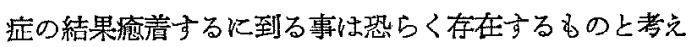
る. 況して常時感染の機会に曝ざれている該部は，炎症 性病変による影響を容易に蒙り，狭小接着状熊と言う解 剖学的不利な条件が拍菈を掛けて，上皮線毛運動の退 行, 腺組織の変性等により, 分汹排泄障㥂をきたし易い であろうし，炎症の慢性化更には瘉着をきたす可能性は 多いものと考元る：こつに搝裂形態異常十炎淀即ち鮕裂 炎の存在を強調する意義があり，臨床的重要性があるの である。

翻つて著者の検索例を钼察するに，癒着例の絶対数は 低率であつた。しかる接着より癒着に 到る Process を 示寸症例は甚だ少かつた，既述せる如く同一症例におい

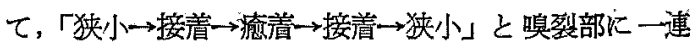
の関俰を示寸所見は連続切片で認める事ができたが，総 て瘉着部位は機質化され，Stationär となつた状態のむ 
の許りであつた，即ち上皮变性，瀾，潰瘍形成像， Fibrin 折出, 好中球・単球・怔夜の出像, 更には Fibroblasten 增生像及び線維化の 所見等々，接着から

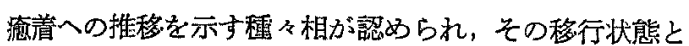
断定し得る症例を得る事ができなかつたのは甚だ残念で ある.唯々1例に括いて，左中甲介接着部の局所に，上 皮剥離著明且細胞漫潤高度を示した症例があり，あるい はこれが接着から瘉着に進行する移行形を意畔するるの であるかも知れない、しかし乍ら斯くの如き所見を呈し たのは僅か 1 例 1 側のみであつた（付図 No. 5, No，6）。 刃粘膜の上皮層が基底膜迄剝離して，鼠中隔及び上・ 中甲介粘膜が接着している場合，上皮值下の細胞成分の 多い固有圆の結合織線維が接し合い境界線を示さず，相 互に移行状態を呈し，微視的にも接着・疮着の判定に苦 しむ例があり，この症例も著者は断定し詳ねている現 在，単に紹介するに止めて置く。

以上の検索成績及び考察より，既述せる新生児に括け る先天性喚裂形成異常例の存在が，再び脚光を浴びてく るのである. 即ち斯かる症例が存在する以上，成人例に 牤ける鮕裂瘉着例総てを，炎症性病变即ち嗅裂炎に上る るのばかりとする考えは改めなければなるまい，尖裂の 癒着あるいは癒着様所見を呈する主な成因に心即ち，

1）胎生期汇原基を有する先天性咱裂形成異常

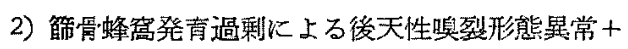
炎应

の二者存在するるのと考觉る事ができるのである，唯々 稀には小览群に極く少数存在した，先天性喚裂狭小ある いは接着例が，生後の発育期に激裂な鼻・副鼻腔炎に袼 患し，これが原因で二次的に嗅裂瘉着更には節骨蜂简発 育不良（含気化不良）を貽したと考光られる埸合も，全 くは否定できないであろう。

投てこの二通りの主たる成因を念頭に置き，著者の检 索例中，成人群汇認められた 4 側の癋着例を検討してみ， る.これ等症例は鼻中隔，上・中甲介之び節骨䗋䇴の炎 症性所見，並びに節骨蜂简含気化状態が，全例炎症性 結果による二次的嗅裂癒着と断定するには, 総ての采件 が具備していない. 即ち全例共に現在浼視的に観察でき るのは, Stationär な所見のみであり，炎症が現在高度 であると断定できるるのが無いからである，粘膜所見に ついて過去の経過を推察するとすれば，線維性洀浪化の 所見を追究する訳であるが，全例瘜着局所に著明な線維 化像を呈するものは無く，既に Stationärになつてい るが故に，粘膜の細胞浸潤も消逐していると考えて上い
であろう. 又過去の生成の歴史をある程度推定できる周 囲骨組䅧にも，その改造線 (Resting Line, Reversal Line 等) の状態，堌生吸収像等上り考光，過去上り現 在に至る過程に，特別激しく炎症性变化を蒙つた所見を 見出す事はできなからた。

こっで新生児嗅裂形成異常例を再び採り上げる，この 例の嗅裂異常側の, 節骨䗋劄 (特に前部) 発育不良の所 見に就いては既述べた通りであるか゚，成人例に㓡ける 症例 6 の嗅裂癒着側の所見とは，発生学的に教察すると 共通点があるのではなかららか．即ち症例 6の嗅裂瘉着 側は，節骨蜂窝発育全く不良で，上奥道，哭裂の形成が 甚だ異常である，故後天的炎症性病变による中・上甲 介瘾着のためにこの異常状態をさたしたと看做すより， この複雑な形態は密万先天的形成異常によつて，節骨蜂 窝発育抑制が生じたか，あるいは先天的に蜂简発育不良 の状態が，喚裂形成異常と共に存在し，午の睢発育を続 け，複雑な上部鼾腔及び右側筑骨蜂简を形成したと考え る方が妥当であるような気がするのは，著者の偏見であ ろらか。

若ししかりとすれば症例 36 か゚两側節骨蜂简発育甚だ 良好, 且癒着側たる左側は特に内側への過剩な膨隆を示

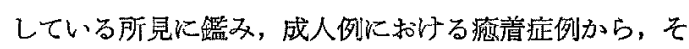
の成因卷推論すると，含気化機転良好の子のは，後天的 炎症性病変に上る二次的瘉着をきたしたもの多く，合気 化機転不良のものは，先天的嗅裂形成異常によるものが 多いと考えられるが、いからであるらか。

叉一方に出いて, 病理組織学的に, 癒着の最も起り易

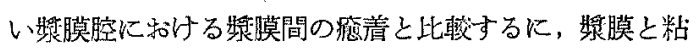
瞙との組織学的な異りを考慮しなければならず, 且頻度

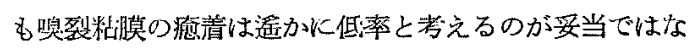
かららか。

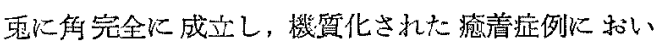
て, その成り立ちを推察する事は甚た困薠であり，単な る想像の域を出ない場合も多い上うである。この閣題の 解明には，先に应べた如く，胎生期以来の嗅裂形成の推 移を追究しなくてはならない。

5. 嗅裂部形態異常の臨床的意義

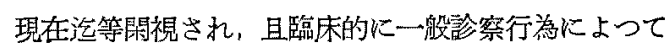
見落され易い部位であるが故に，永く眠らされていた尖 裂部の異常状態を指摘し, 且炎症との関遵性追究され た高橋教授の研究は正に草見である。

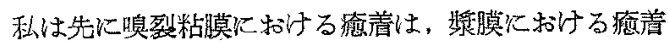

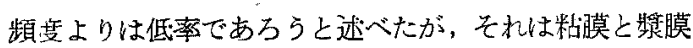


とは自ら組織棈成が暴るからである。

㕛唤裂部瘉着の成因を，先天性噚裂形成異常に上るも

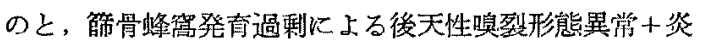
症によるもの（即る嗅裂炎によるもの）との二者に分類 した：しかし成因のいかんに拘らず，斯かる形熊翼常は 臨床的意義に扣いて，共通せる重要なるの有する。こ れを略記すれば次の如くである。

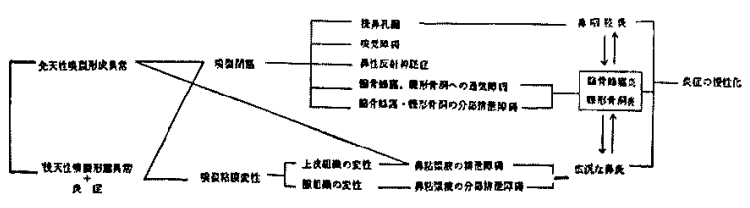

以上の如く臨床上軽視できない症状の原因となり，手 術的に整復しない、限り広範国な分野に不可逆的な影響を 与えるものと考える．この病態を正常化するためには， 巣なる副鼻腔開放手術あるいは學中隔矯正手術のみでは 目的を澾する事はできない，高橋教授の主唱される與腔 整複衍（即方鼻中隔整復術及び 县腔側壁整復術）を併

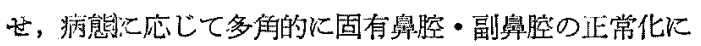
努める可きである. 特に毁中爾整復術施行の場合，鼻中 滆染部の䇫骨正中板，鐁骨等の骨板，更に場合によつて

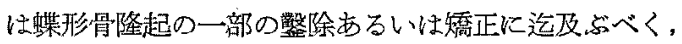
意を払わなくてはならない。

私の臨床的経験では，一般に先天性原因上考学られる 臭裂異常例は，後天性のものに比し，蜂瓷の含気化不

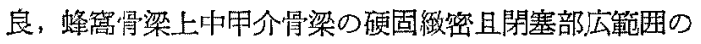
場合が多く，整復燆正更に嗅裂開放が，甚だ困難である よらである。

\section{IV 結論}

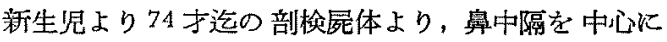
两側上・中甲介，篩骨蜂窝を天蓋壁，紙様板を含めて， 立体的関係を損わずに一塊として剔出した，47例 94 側 (4才以下 9 例， 17 才以上 38 例）について, 前頭断連 続組織標本を作製し，嗅裂部の病理組織学的検索を試 み、次の結果を得た。

1) 嗅裂の䚲態は甚だ複雑であり，狭小・接请・瘉着 を呈するものを認めた.しかし瘉着例の絶詨数は比較的 低率であつた。

2）微妙な接着・狭少の判定を下与場合，標本作步途

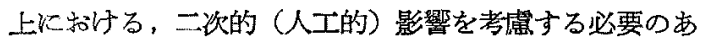
る事垔認めた。

3）接着から瘾着へ到る Process を示す所見は殆ん

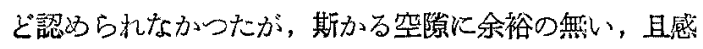

染の機会に懪露される咱裂部に执いて，接着状態が炎症 性病変により，撚着をきたす可能性のある事を認めた。 即も臨床的にも，病理組織学的にも嗅裂炎は存在するも のと考光られる。

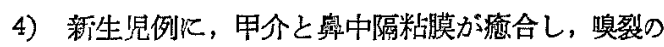
閉塞する所見を認めた。これは先天性嗅裂形成異常と考 える.

5）従つて成人例に括ける嗅裂痛着例は, 総て炎 症性病変によるるのばかりでなく，その成因には，

1. 胎生期に原基を有与る先天性㟫裂形成異常

2. 穊骨䗋璒発云過剩による後天性嗅裂形態異常 + 炎症

の二者存在士る事を明らかにした，しかし乍ら成人例に 末ける機質化せる瘉着所見より，之の成因を推定する事 は甚だ困難である。

6）先天性嗅裂形成異常によるものにせよ，後天的炎 症性嗅裂瘉着にせ上，その臨床的意義は大であり，決し て等閉視すべきでは無い。

\section{参考文献}

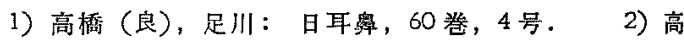
橋, 足川：耳奥展，1巻，2号. 3) 北挶：耳番展， 2 巻, 補册 1.4) 内田：耳䬱展, 2 巻, 補冊 1. 5)

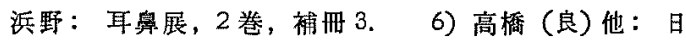

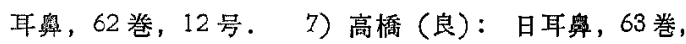

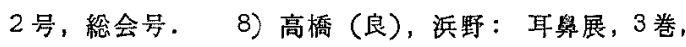
2 号.9) 寺山：耳鼻臨床，48巻，8号。10)山 野辺: 日耳鼻, 56 巻, 8 号, 11) 柴田: 日耳楀， 56 巻, 10 号. 12) 阿部：日耳番, 58 巻, 6 号.

13）牛田：日耳鬼，60巻，4号.14)原子：日医 大誌, 24 替, 1 号. 15) 宮崎：日医大誌, 26 巻, 6 号. 16) 高橋 (研)：耳喉, 32 巻, 1 号. 17) 能 谷: 日耳鼻, 62 巻, 9 号, 18) Weinmann, Sicher: Bone and Bones, 1955. 19) Ash, Raum: Atlas of Otolaryngic Pathology, 1949. 20) Eggston, Wolff: Histopathologie of the Ear, Nose and Throat, 1947. 21) 高橋（良）：日本耳番咽喉科全書，第2巻 第 2 冊. 22) 西端：日本耳鼻咽喉科全書, 第 2 巻, 第 1 冊. 23) 西端: 日本耳奥咽喉科全書, 第 2 巻, 第 6 冊. 24) 高橋 (良): 耳鼻咽喉科学, 上巻.

25) 後藤 (敏)：耳咽喉科学, 上巻. 26) 津崎： 人体発生学.

\section{付図説明}

(No. 1) 症例 51 . 中部. 右上〜中甲介移行部は䨨 
北嶋論文付図 (I)

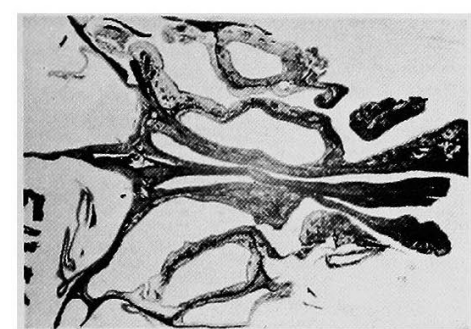

(No. 1)

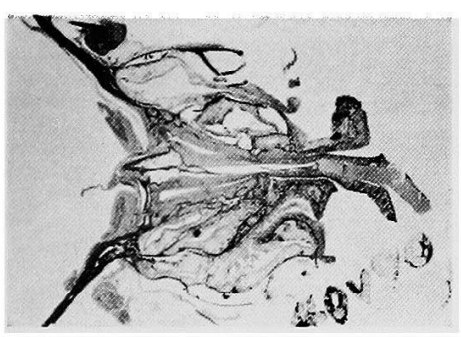

(No. 3)

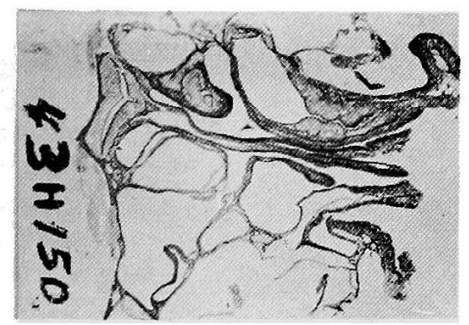

(No. 5)

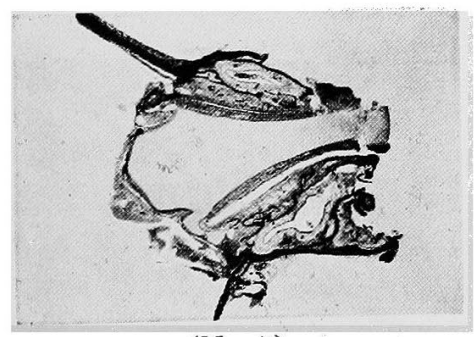

(No. 7)

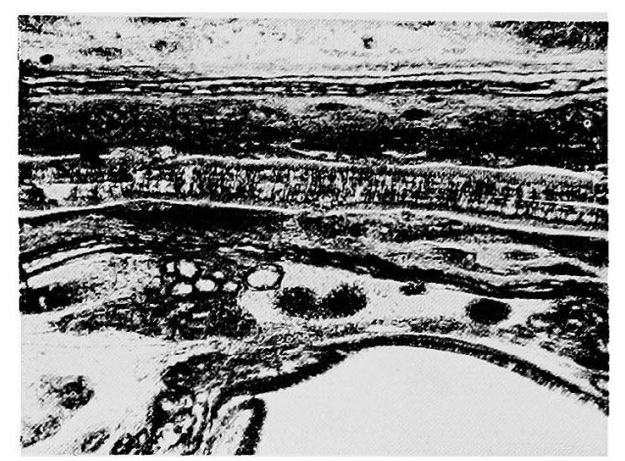

(No. 2)

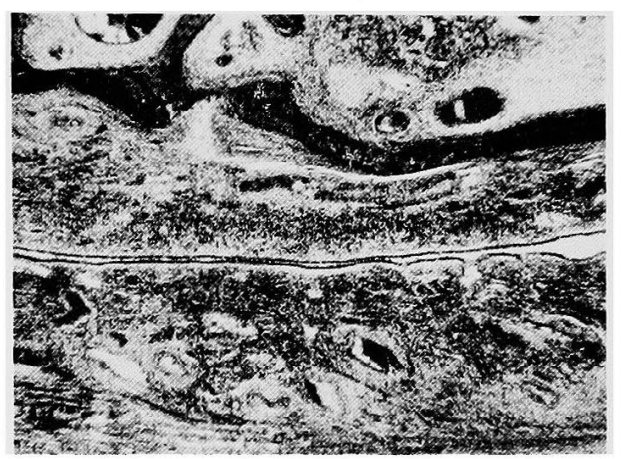

(No. 4)

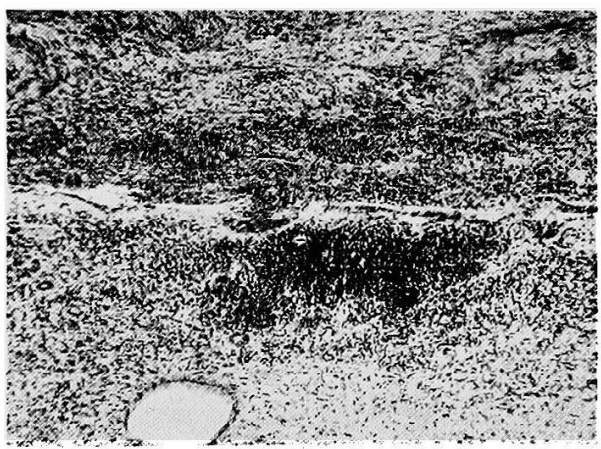

(No. 6)

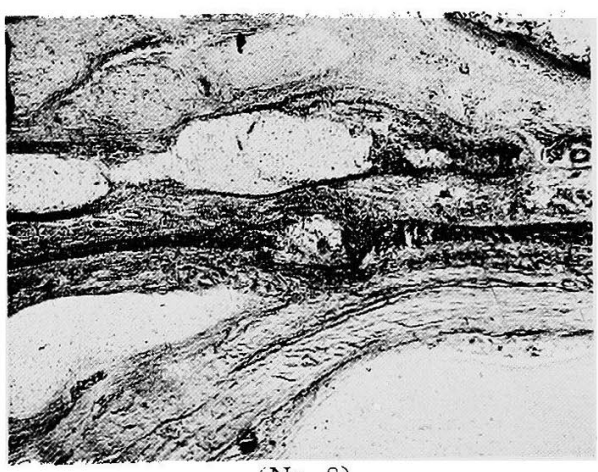

(No. 8) 


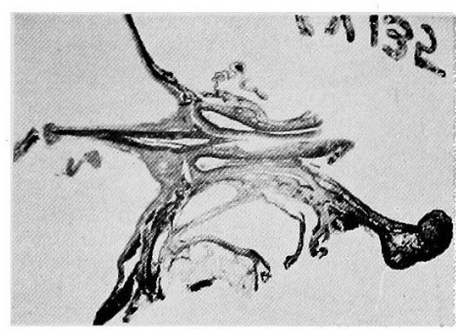

(No. 9)

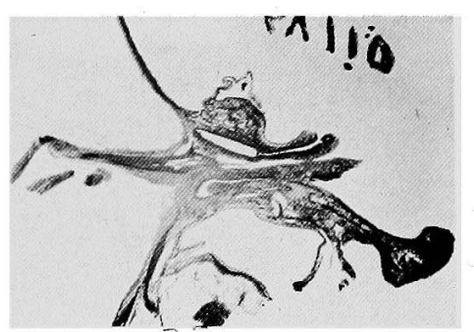

(No. 11)

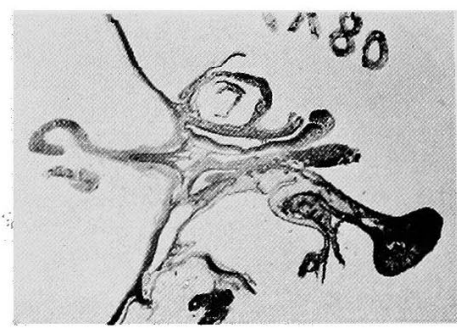

(No. 13)

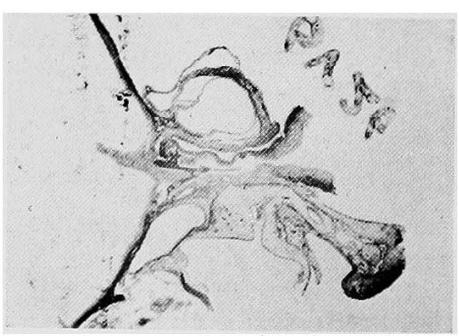

(No. 15)

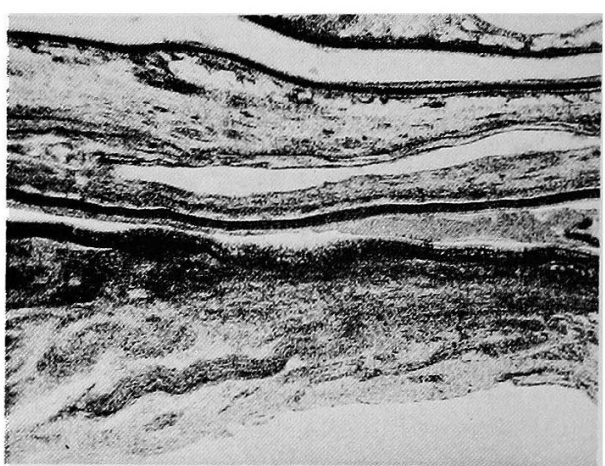

(No. 10)

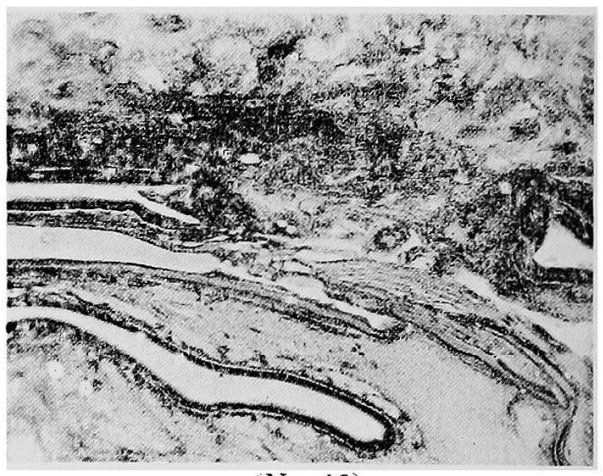

(No. 12)

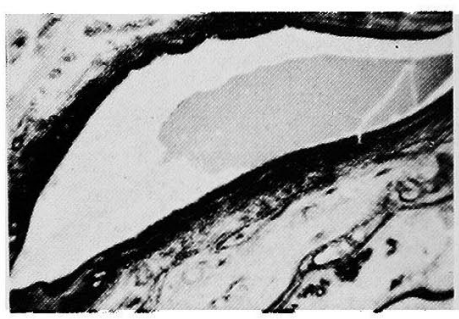

(No. 14)

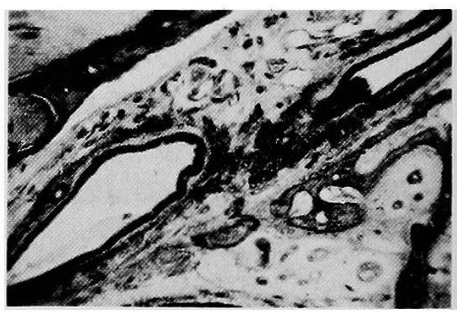

(No. 16) 
北嶋論文付図（四）

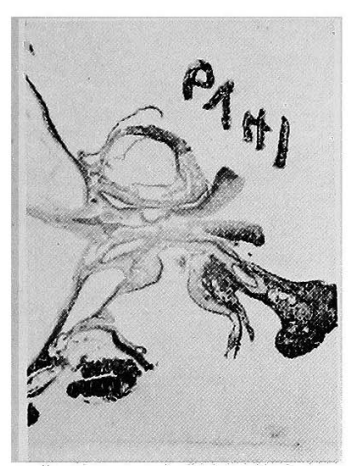

(No. 17)

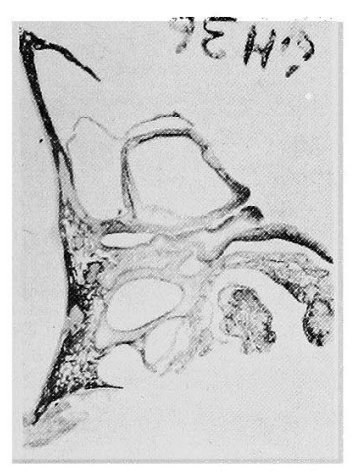

(No. 19)

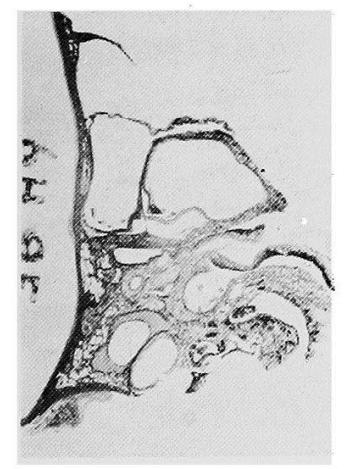

(No. 21)

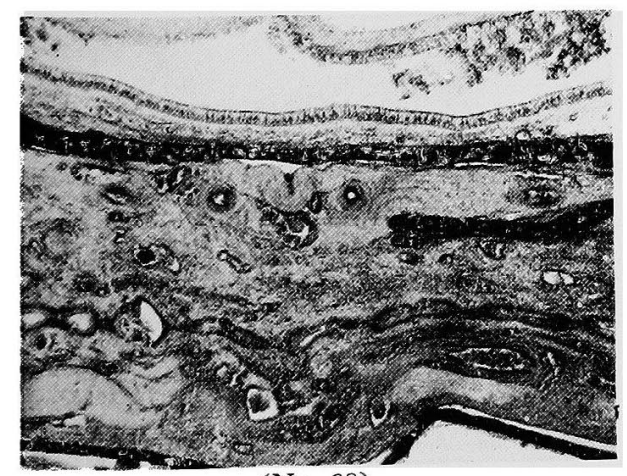

(No. 23)

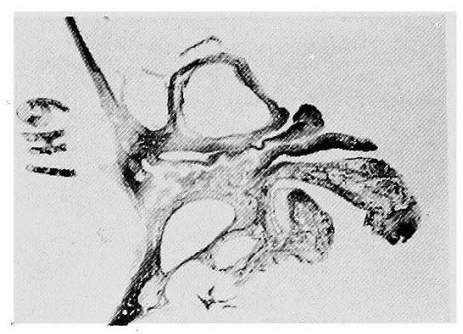

(No. 18)

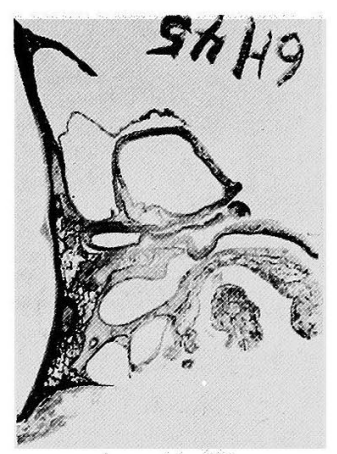

(No. 20)

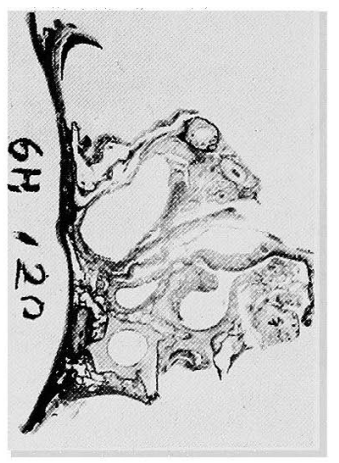

(No. 22)

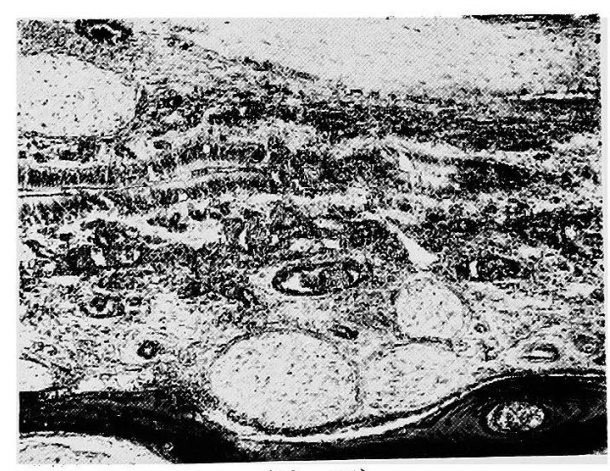

(No. 24) 
北嶋論文付図（N)

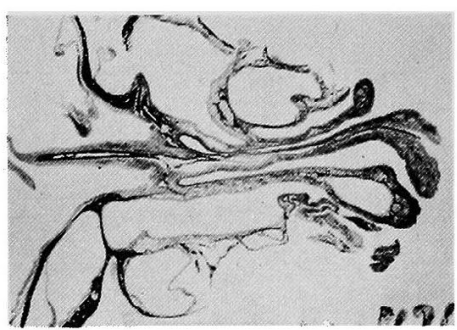

(No. 25)

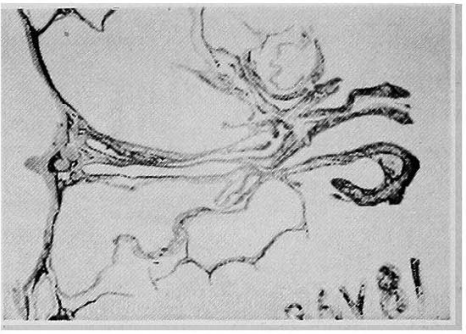

(No. 26)

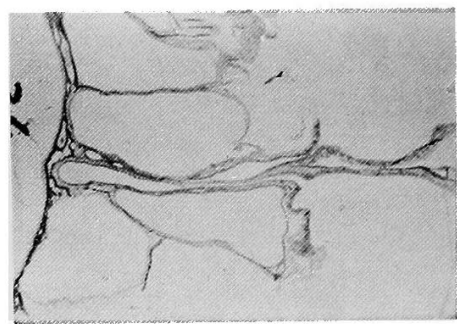

(No. 28)

(No. 27)

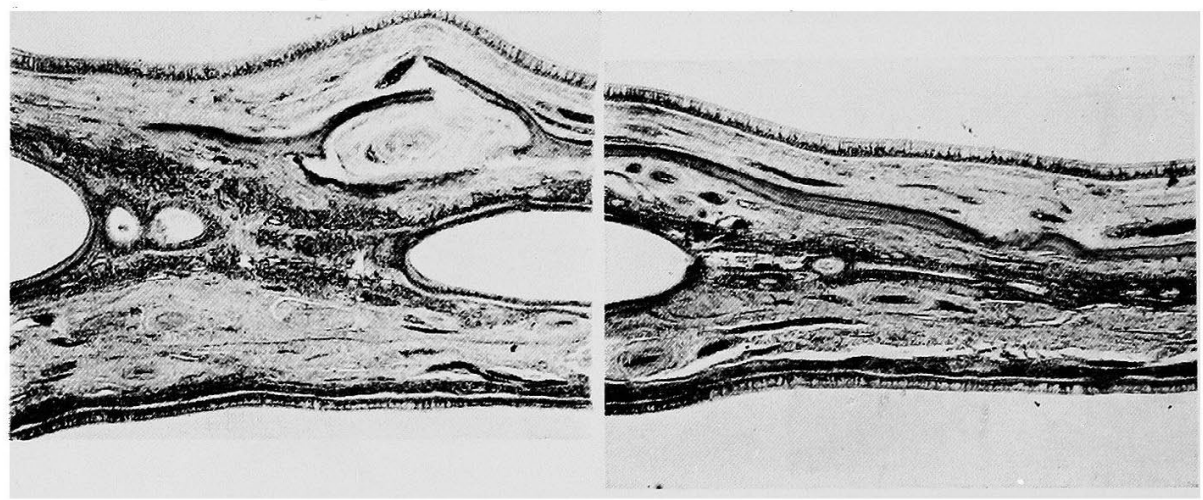

(No. 29, 30)

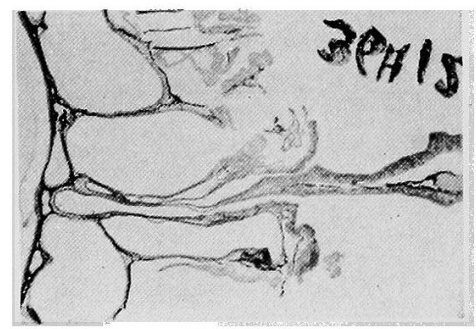

(No. 31)

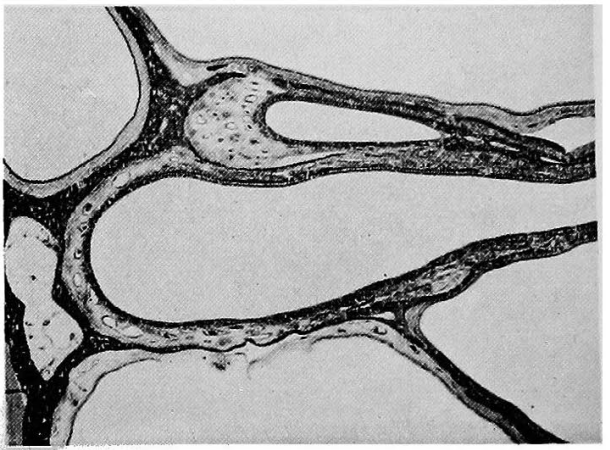

(No. 32) 
中隔と接着.や〉上部の鼻中隔の小骨折が接着の 原因であららか。

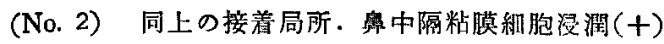
甲介粘膜細胞浸潤 $( \pm)$ ，上波組䋨の䟝離，変性 は無い。

(No. 3) 症例 40. 前部. 右上〜中甲介移行部及び

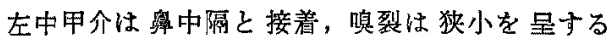
か，節骨正中板の骨折，骨・軟骨接合部の枟移並 に粘膜㔀蜼を認める。

(No. 4) 同上の左倒接着局所.甲介窈中隔粘膜共に 細胞浸洞軽度なるも，上皮組織の剔離あり。局所 微視写真の及では，二次的接着の観察不能である。

(No. 5) 症例 43. 後部. 左中甲介〜鼻中隔接着.

中隔に粘獏㔀離，骨折を認め，巨視的飞恃二次 的接着像と考克られるが。

（No. 6）同上接着局所．甲介-率中隔共に上皮組織 虽離し，一部変性，局所の及䋖胞浸润著明，両粘 膜の瘾合移行像の如き所見を呈す。

(No. 7) 症例 37. 前部.

(No. 8) 同上中部. 左喼裂上部の新生骨（以下本症 例の附図江渄 33 巻 5 号に揭载予定).

(No. $9,11,13$, 15) 症例 6. 切片番前135, 前 110 , 前 80 ，前 26，前部～中前部． 右中甲介～鼠中谝限 局性に瘾着。後部へ到るに従い，療着籍因抾大， 鮕裂小となる。

（No. 10）同上. 切片番号前 135，右嗅裂炏小，詝溜 物あり.

(No. 12) 同上. 切片番号前 110. 右㖟裂限局性瘾着. (No. 14) 同上. 切片番号前 80 . 右嗅裂最上部.
（No. 16）同上. 切片番号前 26. 嗅裂は更に㽷着し， 上部下部に峰简様に分たれる。

(No. 17. 18.19，20，21，22) 同上. 切片番号前 41 ， 後 1 , 後 36 , 後 45 , 後 85 , 後 120 . 後部一行くに良

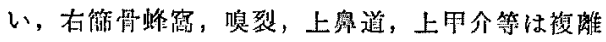
な形熊を示す

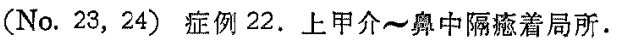

(No. $25,26,28,31$ ) 症例 36 . 最前部 後部. 切片 番号前 420 , 前 81 , 後 70 , 後 120 .

（No. 27）同上. 切片番号前81. 左嗅裂㷋小及び接着. (No. 29, 30) 同上. 切片番号後 71 . 左喚裂痖着部. 上部及び下部。

（No.32）同上. 切片番号後 120, 两側嗔裂の 比校像, 滤着侧と非瘾着侧の炎症性所見に差異を認めな w.

稿を終るに臨み，御指導，御校閲晹りし，恩師大 藤敏三教授，永井氾傅士に宊心上り感謝致します 亦研究継繶儿際し御便宜頂きし下谷病院長内山圭梧

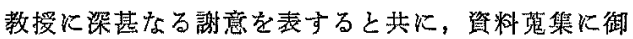
尽力下さつた東京都監察医務院越永博士，吉村博士 に深謝致します。

本論文の要旨は昭和 35 年 6 月 24 日, 日耳鼻関東 地方会第359回例会，及び昭和 35 年 11 月 6 日，日 本医科大学医学会に於て発表。一部怔日耳鼻関東地

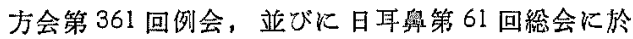
て追加した。

$$
\text { （原稿到着 }=\text { 昭和 } 35.12 .2 \text { 日） }
$$

